dr hab. inz. Marian Medwid prof. nadzw.

dr inj. Rafat Cichy

Instytut Pojazdów Szynowych ,TABOR”

\title{
Proces modelowania modułowego systemu transportowego
}

\author{
Przedmiotem opracowania jest merytoryczna prezentacja procesu tworzenia \\ innowacyjnego systemu transportowego do przewozu naczep drogowych $w$ \\ ruchu kombinowanym kolejowo-drogowym, nie majacego odniesienia do \\ znanych systemów transportowych. \\ W opracowaniu przedstawiono droge dochodzenia od pierwotnego pomystu \\ koncepcyjnego do dojrzatej konstrukcji systemu. Przedstawione w artykule \\ rozwiqzania sq częścia prac prowadzonych od wielu lat $w$ Instytucie \\ Pojazdów Szynowych „Tabor” w Poznaniu projektów majacych na celu \\ przywrócenie równowagi $w$ dysproporcji pomiędzy przewozami drogowymi $i$ \\ kolejowymi. Wyniki prac badawczych sq rezultatem zrealizowanego projektu \\ rozwojowego $\mathrm{nr}$ 10-0065-10 pt. System transportu naczep drogowych na \\ wózkach kolejowych w kombinowanym ruchu kolejowo drogowym.
}

\section{Wstęp}

Transport intermodalny w tym kolejowo-drogowy jest dziedziną transportu zapoczątkowaną w latach 60 ubiegłego wieku kiedy po raz pierwszy wprowadzono do eksploatacji w Stanach Zjednoczonych Ameryki Północnej, jednostkę ładunkową nazwaną kontenerem.

Kontener umożliwił przewóz ładunków od nadawcy do odbiorcy różnymi środkami transportu, bez przeładunku towaru, który $\mathrm{w}$ całym procesie transportu intermodalnego pozostaje w tym samym kontenerze. Taka technologia transportu umożliwiła spedytorom osiagnięcie szeregu korzyści, miedzy innymi:

- uproszczono i radykalnie skrócono czas przeładunku towarów,

- wprowadzono odprawy celne na terenie kraju, a nie na granicy,

- ograniczono ilość uszkodzonego ładunku,

- zmniejszono straty wynikające z kradzieży ładunku.

Za ojca transportu kontenerowego uznany jest Malcom McLean, założyciel przedsiębiorstwa żeglugowego Sea-Land, które zainaugurowało w maju 1966 roku przewóz kontenerów przez Atlantyk. Rozwijający się intensywnie w ostatnim dwudziestoleciu towarowy transport drogowy przejął większość przewożonych towarów ze środków transportu kolejowego. Intensywny wzrost udziału transportu drogowego w przewozach towarowych doprowadził do negatywnych skutków objawiających się zatłoczeniem dróg i autostrad, szybką degradacją dróg, szkodliwym oddziaływaniem na środowisko naturalne.
W dążeniu do zrównoważonego rozwoju transportu drogowego i kolejowego podjęto w Europie prace badawcze nad poszukiwaniem systemów transportowych pozwalających przywrócić równowagę i odwrócić niekorzystną tendencję $\mathrm{w}$ realizacji przewozów towarów środkami transportu drogowego i kolejowego.

\section{Modelowanie struktury systemu}

Wieloletnie doświadczenia nabyte podczas realizacji w IPS „TABOR” prac rozwojowych nad poszukiwaniem innowacyjnych rozwiązań systemów transportowych przeznaczonych do transportu kombinowanego prowadzą do konkluzji na podstawie której można wyróżnić dwa kierunki rozwoju systemów transportowych do przewozu naczep drogowych. Do pierwszego można zaliczyć systemy bimodalne gdzie naczepy drogowe $\mathrm{w}$ uformowaniu kolejowym są przewożone na wózkach kolejowych zaopatrzonych w specjalne adaptery. W tym przypadku zawsze występuje poziomy przeładunek naczep $\mathrm{z}$ trakcji drogowej na kolejową i odwrotnie.

Drugi kierunek rozwoju dotyczy transportu naczep drogowych na specjalistycznych wagonach platformach $\mathrm{z}$ poziomym lub pionowym przeładunkiem naczep.

Zalety i wady tych rozwiązań przedstawiano w wielu pracach opisujących systemy transportowe $[1,2,3]$. Prezentowana $\mathrm{w}$ niniejszej publikacji koncepcja łączy niektóre cechy systemów adapterowych i wagonów platform. 


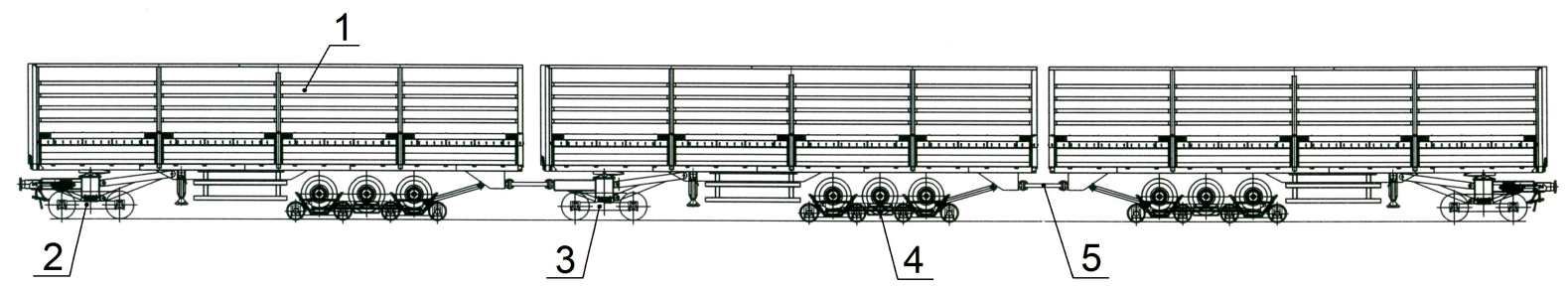

Rys. 2.1 - Pociąg wyposażony na obu końcach w wózki z urządzeniami pociagowo-zderznymi oraz ze sztywnym połączeniem międzynaczepnym

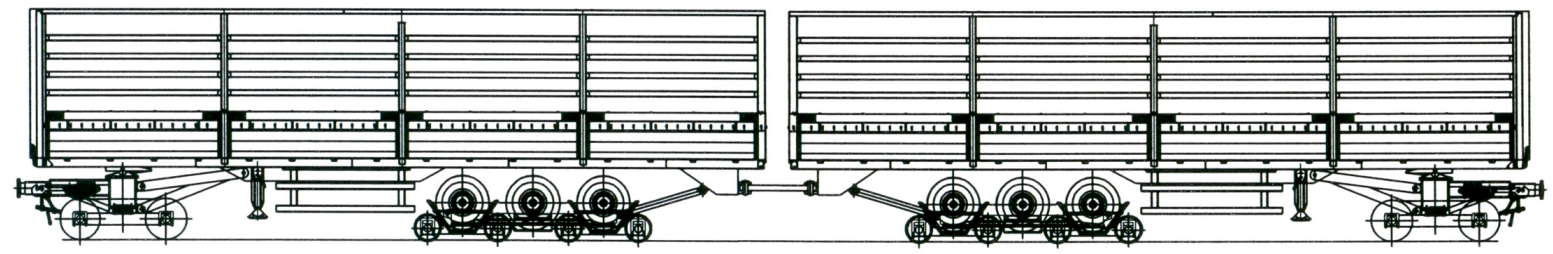

Rys. 2.2 - Moduł dwunaczepowy wyposażony na obu końcach w urządzenia pociagowo-zderzne

Pierwotną ideę koncepcji systemu przedstawiono na rys. 2.1 i 2.2 , gdzie rys. 2.1 pokazuje skład pociagu złożony $\mathrm{z}$ naczep drogowych, a rys. 2.2 dwunaczepowy moduł, z którego można tworzyć skład pociagu z określonej liczby modułów.

Podstawowe części składowe pociagu rys. 3.1 to:

- naczepa drogowa 1

- przedni układ jezdny - końcowy 2

- przedni układ jezdny - pośredni 3

- tylny układ jezdny 4

- cięgło międzynaczepowe 5.

Naczepy 1 składu pociagu zwrócone są ścianą czołową w tę samą stronę natomiast ostatnia naczepa ma ścianę czołową skierowaną w stronę przeciwną.

Przedstawiony na rys. 2.2 symetryczny moduł dwunaczepowy jest złożony $z$ dwóch przednich układów jezdnych - końcowych, dwóch tylnych układów jezdnych oraz dwóch naczep zwróconych do siebie tyłem i wzajemnie połączonych cięgłem międzynaczepowym.

Bardziej szczegółowo naczepę z przednim układem jezdnym - pośrednim pokazano na rys. 2.3 , a $z$ przednim układem jezdnym - końcowym na rys. 2.4.

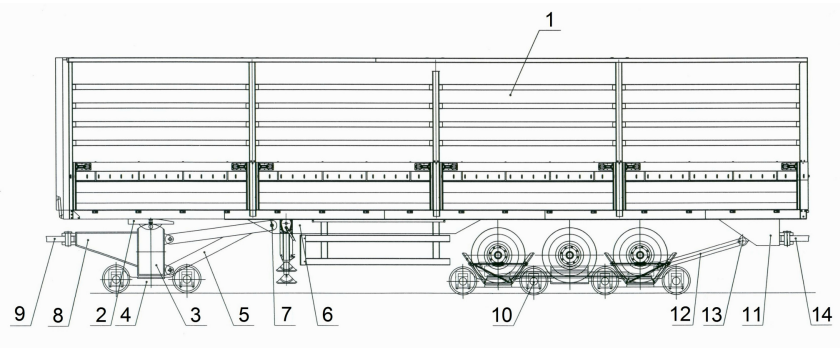

Rys. 2.3 - Naczepa na wózkach kolejowych z wózkiem przednim przystosowanym do łączenia międzynaczepowego

Przód naczepy 1 (rys. 2.3) oparto na siodle 2, kolumny adaptera 3 odpowiednio zamocowanej na ramie wózka 4. Urządzenie cięgłowe 5 łączy w sposób sztywny kolumnę adaptera $3 \mathrm{z}$ ramą nośną naczepy 6 za pomocą sworzni 7 lub innego rodzaju urządzeń sprzęgowych. Kolumnę adaptera 3 wyposażono w

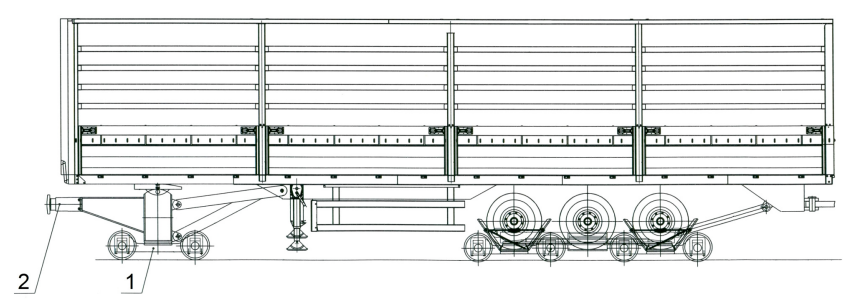

Rys. 2.4 - Naczepa na wózkach kolejowych z wózkiem przednim wyposażonym w typowe urządzenia pociągowo-zderzne

belkę nośną 8 zakończoną wspornikiem do którego zamocowano przegubowo cięgło międzynaczepowe 9. Koła drogowe naczepy posadowiono na ramie nośnej tylnego układu jezdnego 10 zamocowanej do wspornika 11 ramy naczepy 6 za pomocą cięgieł 12 połączonych z wspornikiem 11 sworzniami 13 . Wspornik 11 wykorzystano również do połączenia sąsiedniej naczepy cięgłem międzynaczepowym 14.

$\mathrm{Na}$ rys. 2.4 pokazano naczepe zamocowaną $\mathrm{z}$ przodu do przedniego, końcowego układu jezdnego, gdzie adapter 1 wyposażono w urządzenia pociagowozderzne 2 przeznaczone do połączenia składu pociągu $\mathrm{z}$ lokomotywą lub $\mathrm{w}$ odmianie wykonania pociagu złożonego $\mathrm{z}$ modułów dwunaczepowych do połączenia modułów pociagu.

Cechą charakterystyczną prezentowanego rozwiązania jest usytuowanie w tym samym miejscu punktów podparcia ramy naczepy $\mathrm{w}$ ruchu drogowym i w uformowaniu kolejowym. Brak połączenia pomiędzy wózkiem przednim i tylnym przypomina rozwiązania $\mathrm{z}$ transportu bimodalnego. Takie rozwiązanie takie pozwoliło weliminować niekorzystny wpływ rozsunięcia miejsc podparcia naczepy występujący w systemach bimodalnych, zachowując jednocześnie pozytywny stosunek masy przewożonego towaru do masy brutto całego pojazdu. 


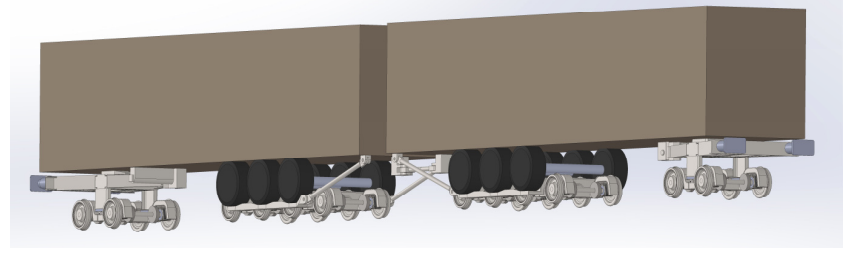

Rys. 2.5 - Model przestrzenny modułu dwunaczepowego

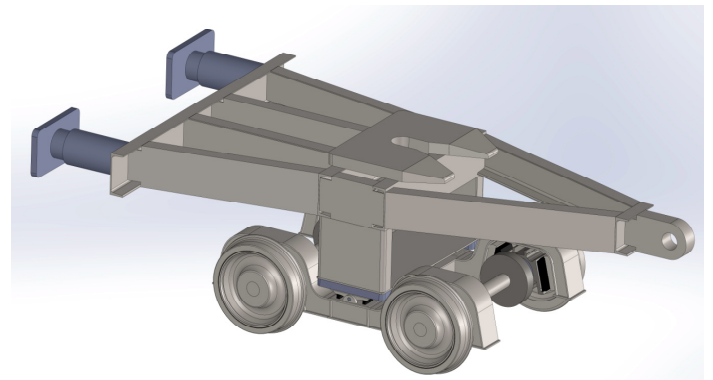

Rys. 2.6 - Model przedniego układu jezdneg

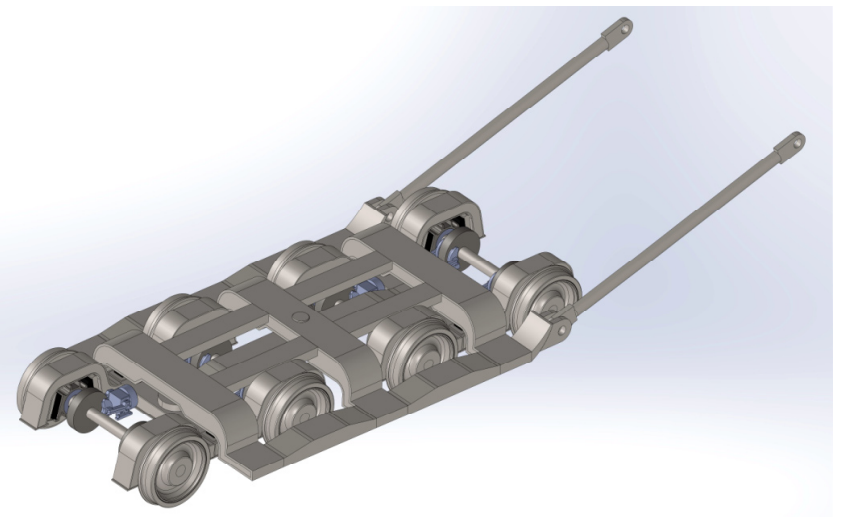

Rys. 2.7 - Model tylnego układu jezdnego

Na rysunkach 2.5, 2.6 i 2.7 przedstawiono modele przestrzenne opisanej wyżej koncepcji kolejowych układów jezdnych gdzie na rys. 2.5 pokazano model modułu dwunaczepnego, a na rys. 2.6 i 2.7 odpowiednio model przedniego i tylnego układu jezdnego. Natomiast rysunki 2.8 i 2.9 prezentują główne części składowe układów jezdnych.

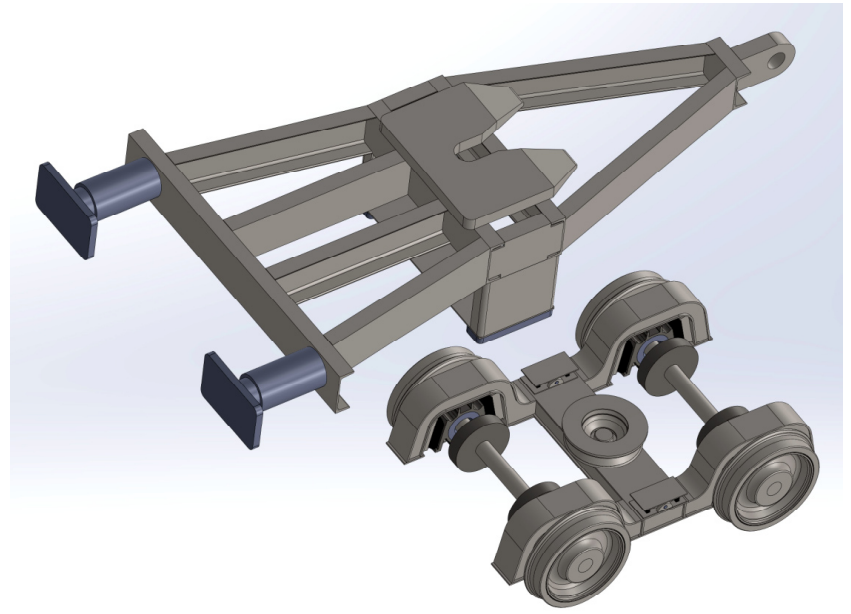

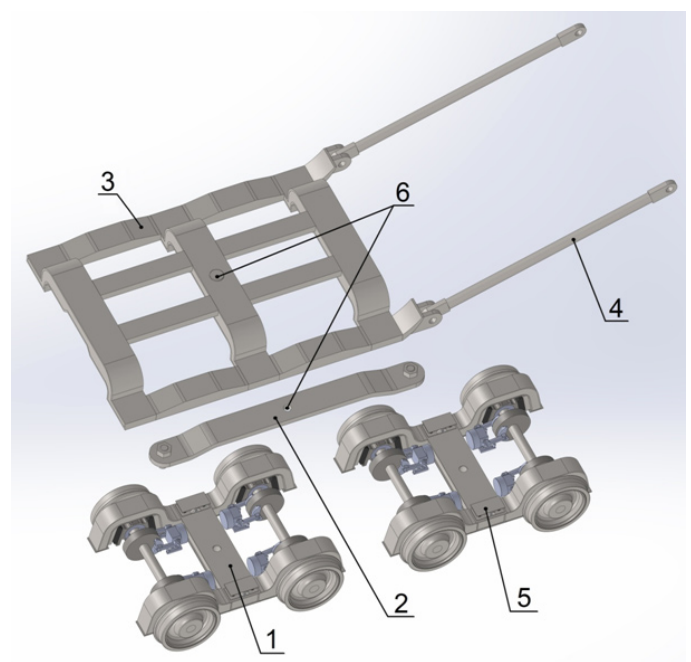

Rys. 2.9 - Model podstawowych zespołów tylnego układu jezdnego

Na rys. 2.9 pokazano części składowe tylnego układu jezdnego, który zbudowano z dwóch wózków dwuosiowych 1 , belki podłużnej 2 , ramy nośnej 3 oraz cięgieł 4. Wózki połączono belką podłużną stanowiąca łącznik kinematyczny i siłowy zapewniający obrót wózków względem osi pionowej czopów skrętu oraz przenoszenie sił wzdłużnych pomiędzy wózkami. Ramę nośną oparto na czterech ślizgach bocznych 5 wózków, a połączenie obrotowe ramy nośnej względem osi pionowej zrealizowano za pomocą centralnego czopa skrętu 6 zlokalizowanego na części środkowej belki podłużnej i ramy nośnej. Czop skrętu 6 ramy nośnej przenosi tylko siły poziome. Powiązanie wózków belką podłużną przy równoczesnym połączeniu obrotowym belki podłużnej z ramą nośną sprawia, że przy poprzecznym przemieszczeniu jednego wózka następuje wymuszenie poprzecznego przemieszczenia drugiego wózka $\mathrm{w}$ przeciwnym kierunku, co może niekorzystnie wpływać na utrzymanie stabilnego ruchu tylnego układu jezdnego.

Przedstawiona na rysunkach koncepcja jest jednym z przykładowych, analizowanych wariantów gdzie konstrukcje adaptera przedniego układu jezdnego oraz ramę nośną tylnego układu jezdnego oparto na wózkach na przegubowych ślizgach bocznych umieszczonych na podłużnicach ramy wózka. Szczegółowe rozwiązanie zaprezentowano na rys. $2.9 \mathrm{~b}$.

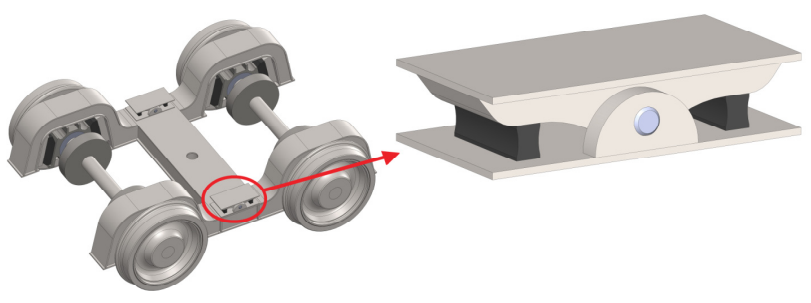

Rys. 2.10 - Model wózka z pierwszym stopniem usprężynowania i przegubowymi ślizgami na podłużnicach ramy 
Przykład wariantowego rozwiązania oparcia adaptera na wózku przedstawiono na rys. 2.11 gdzie ślizgi boczne usytuowano na zewnątrz podłużnicy ramy wózka. Analizowany wariant rozwiązania zawiera jeden stopień usprężynowania. Zastosowano gumowe sprężyny typu CHEVRON zabudowane między oprawą łożysk a ramą wózka. Ramę adaptera przedniego układu jezdnego oraz ramę nośną tylnego układu jezdnego oparto na ramach wózków za pośrednictwem ślizgów bocznych zabudowanych wachliwe na podłużnicach ram wózków.

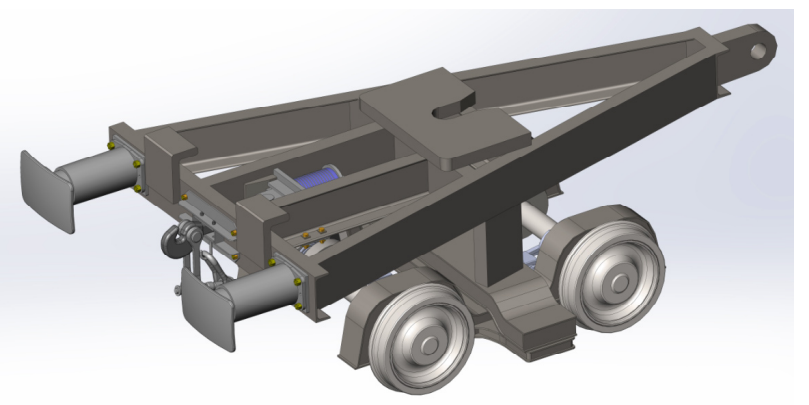

Rys. 2.11 - Przedni układ jezdny ze ślizgami umiejscowionymi na zewnątrz podłużnicach ramy wózka

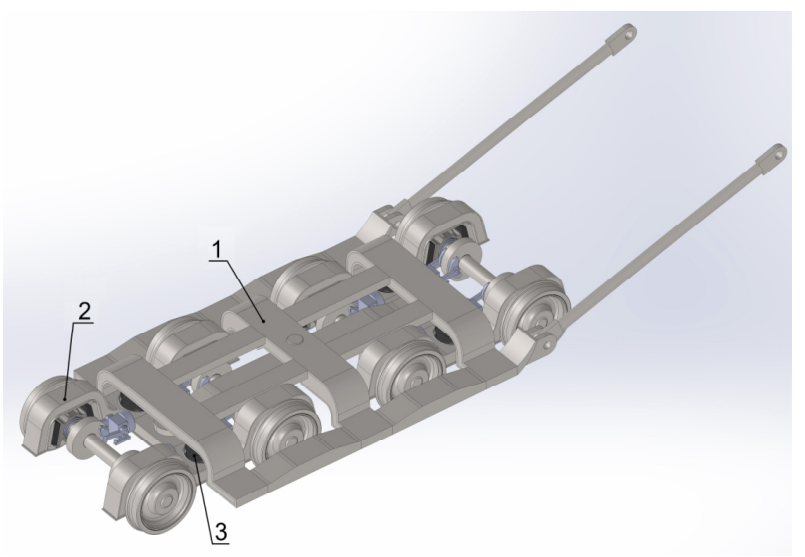

Rys. 2.12 - Tylny układ jezdny z dwoma stopniami usprężynowania

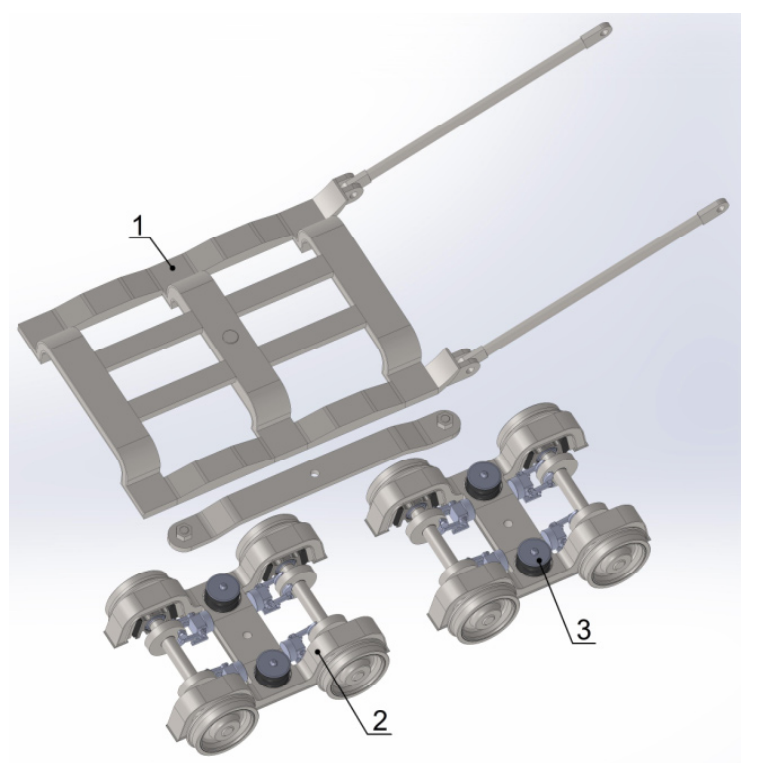

Rys. 2.13 - Podstawowe zespoły tylnego układu jezdnego z 2-oma stopniami usprężynowania

Na rysunkach 2.12 i 2.13 zaprezentowano budowę tylnego układu jezdnego $\mathrm{z}$ dwoma stopniami usprężynowania, gdzie ramę nośną 1 oparto na wózkach 2 za pośrednictwem gumowych podpór sprężystych 3 zaadaptowanych z oparcia pudła na wózkach lokomotywy ET22.

Wykorzystanie tych podpór jest możliwe ponieważ charakterystyka sztywności pionowej i poziomej podpór odpowiada wymaganiom wynikających z obciążeń pionowych i przemieszczeń poprzecznych podpór podczas przejazdu przez łuki torów o małych promieniach - rys. 2.14 .

Na rys. 2.15 i 2.16 przedstawiono kolejny wariant konstrukcji tylnego układu jezdnego gdzie wózki 1 połączono z ramą nośną 2 za pomocą cięgieł prowadzących 3 przez co wyeliminowano szkodliwe sprzężenie poprzecznych przemieszczeń wózków występujące $\mathrm{w}$ koncepcji przedstawionej na rys. 2.8, 2.10, 2.12, 2.13 gdzie wózki połączono belką podłużną.

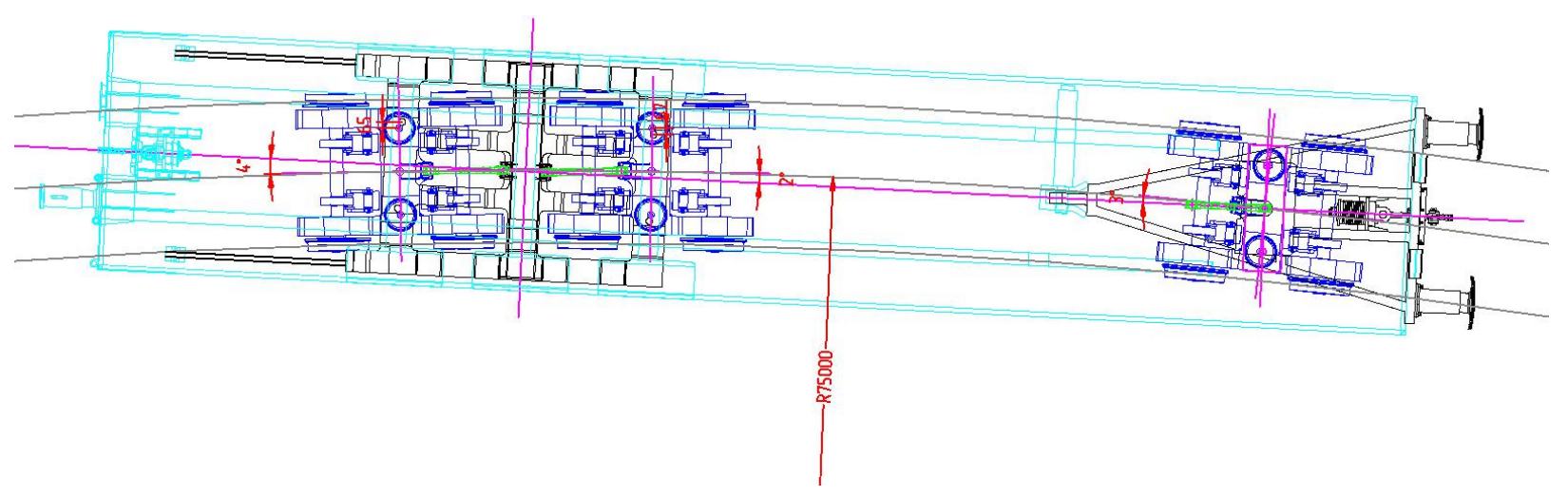

Rys. 2.14 - Przejazd układu z 2 stopniami usprężynowania przez luk o promieniu $\mathrm{R}=75 \mathrm{~m}$ 


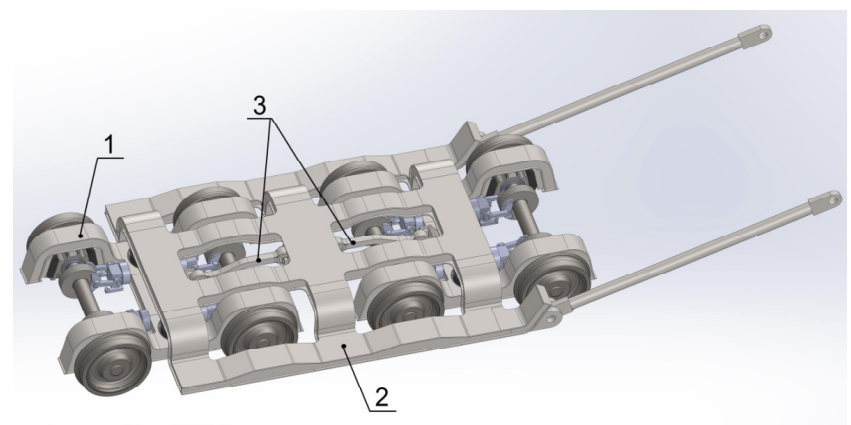

Rys. 2.15 - Połączenie wózków z tylnego układu jezdnego za pomocą przegubowych ciegieł

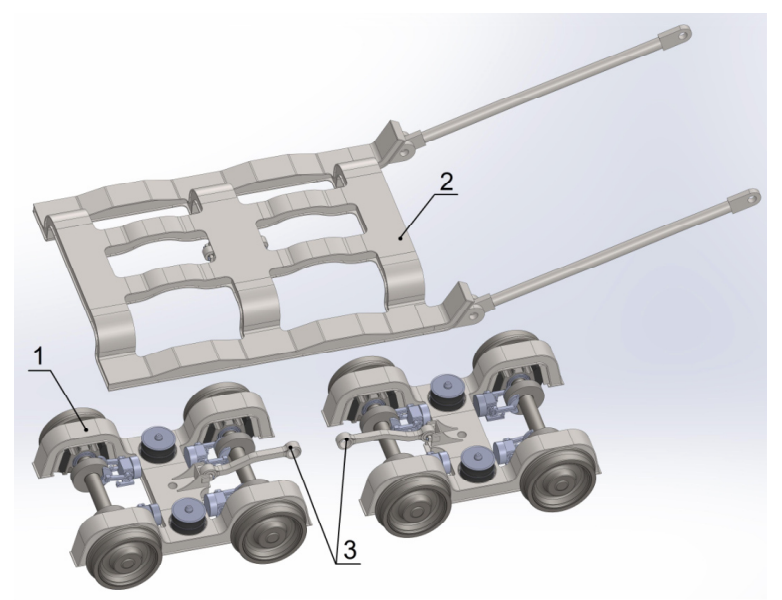

Rys. 2.16 - Podstawowe zespoły tylnego układu jezdnego z przegubowymi cięgłami prowadzącymi

Rozwój konstrukcji zaprezentowany powyżej był tylko częścią prowadzonych analiz. Daje on jednak podstawę do zrozumienia jak zmieniała się konstrukcja podczas jej tworzenia. Na podstawie uzyskanych wyników postanowiono przeprowadzić szczegółowe analizy kinematyczne.

Kolejny etap symulacyjnych analiz koncepcyjnych dotyczył badań kinematyki i przemieszczeń poprzecznych opon drogowych umieszczonych na półkach ramy nośnej tylnego układu jezdnego. Podczas przejazdu przez łuk o małych promieniach np. R90 m występują niebezpieczne (kolizyjne) zbliżenia opon do kół zestawów kołowych wózków (przy średnicy tocznej kół $580 \mathrm{~mm}$ ).

Przykładowe wyniki analiz wykonanych dla opon 22,5" i 19,5' oraz luków toru o promieniu $90 \mathrm{~m}$ i $120 \mathrm{~m}$ pokazano na rys. $2.17,2.18,2.19 \mathrm{i}$ 2.20 .

Dla przedstawionych analiz przyjęto standardowy poprzeczny rozstaw kół naczepy $2100 \mathrm{~mm}$, który jest bardziej korzystny dla badanego rozwiązania od innego standardowego rozstawu $-2040 \mathrm{~mm}$.

Korzyść ta wynika z większej przestrzeni pomiędzy kołami kolejowymi a kołami naczepy drogowej.

Do symulacji przyjęto centralne ułożenie osi wzdłużnej naczepy względem osi wzdłużnej platformy tylnego układu jezdnego. W warunkach rzeczywistych, osie symetrii mogą być od siebie odsu- nięte o wielkość luzu poprzecznego pomiędzy kołami drogowymi a ramą platformy tylnego układu jezdnego.

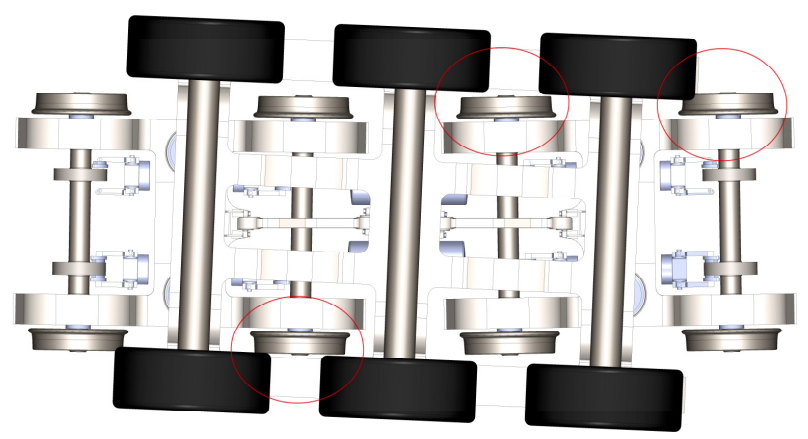

Rys. 2.17 - Symulacja na łuku 90 m koła drogowe 19,5"

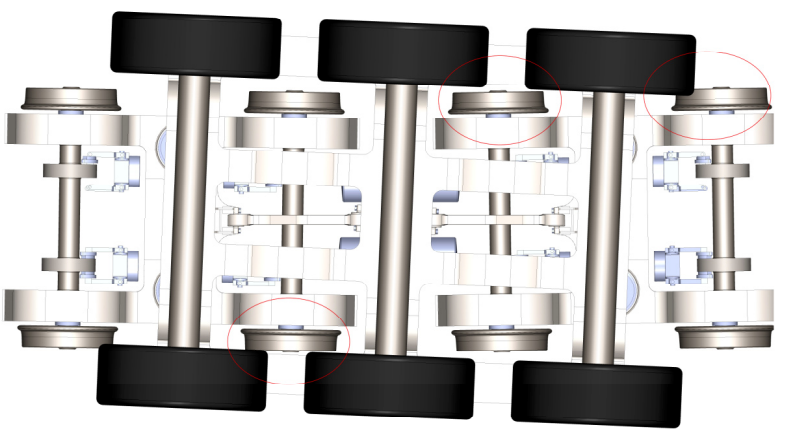

Rys. 2.18 - Symulacja na łuku 90 m koła drogowe 22,5"

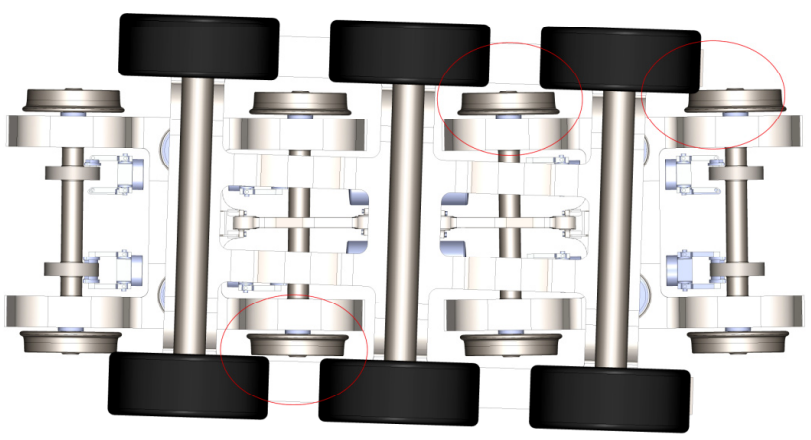

Rys. 2.19 - Symulacja na łuku 120 m koła drogowe 19,5"

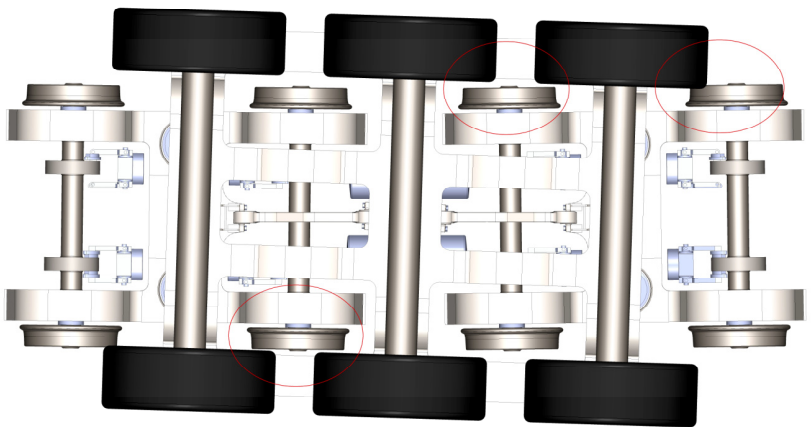

Rys. 2.20 - Symulacja na łuku $120 \mathrm{~m}$ koła drogowe 22,5"

Mimo, że analizy wykonano metodą uproszczona, która nie uwzględnia wszystkich istniejących luzów poprzecznych wynikających $\mathrm{z}$ konstrukcji układu biegowego i parametrów geometrycznych toru, już na podstawie tej analizy można ocenić nierealność tej koncepcji budowy tylnego układu jezdnego pomimo zalety jaka jest zwarta konstrukcja. 
$\mathrm{Na}$ podstawie prezentowanych wyników analiz można zauważyć, że nawet przejazd układu przez większy promień tuku np. $120 \mathrm{~m}$ nie poprawia wystarczająco sytuacji.

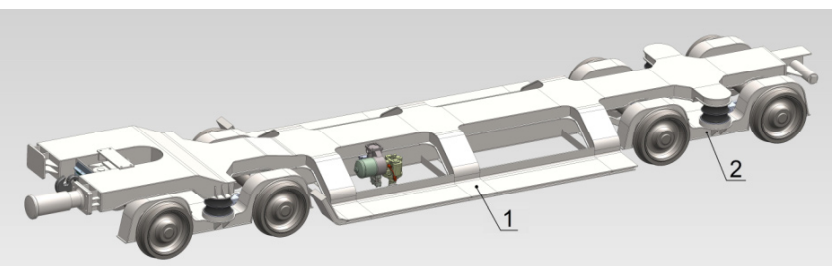

Rys. 2.21 - Koncepcja tylnego układu jezdnego z wózkami umieszczonym na końcach ramy

Przystapiono do kolejnego wariantu koncepcji tylnego układu jezdnego przedstawionego na rys. 2.21, gdzie ramę nośną wydłużono a wózki umieszczono na końcach ramy. W ten sposób uzyskano wolną przestrzeń do bezkolizyjnego oparcia kół drogowych naczepy na półkach ramy nośnej, odpowiednio oddalonych od kół zestawów kołowych wózków.

Dodatkową zaletą tego rozwiązania jest możliwość zabudowy pod ramą nośną elementów armatury hamulcowej na co brakowało miejsca w poprzednio analizowanej koncepcji. Przekrój przez wózek tylny w wariancie z gumami ET22 przedstawiono na rys. 2.22.

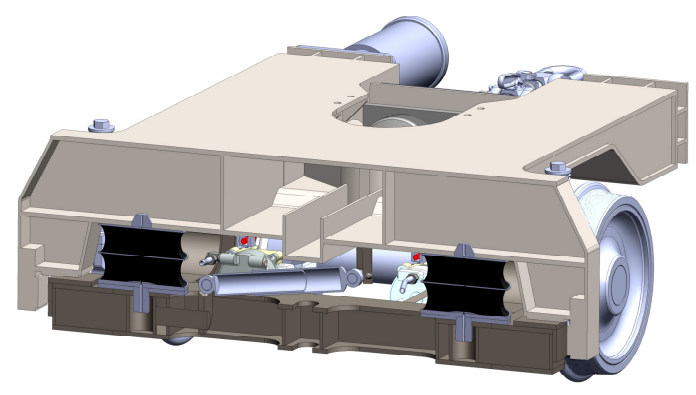

Rys. 2.22 - Przekrój przez wózek tylny w wariancie z gumami ET22
Konsekwencją takiego usytuowania wózków tylnego układu jezdnego jest stworzenie pojazdu trzywózkowego gdzie wózek środkowy jest umieszczony w pobliżu połowy rozstawu wózków skrajnych.

$\mathrm{Na}$ rys. 2.23 pokazano ustawienie wózków takiego pojazdu w huku toru o promieniu 90 m gdzie wózek środkowy przemieszcza się poprzecznie pod nadwoziem o $\sim 110 \mathrm{~mm}$. Nie jest możliwe zrealizowanie tak dużych przemieszczeń za pomocą podpór sprężystych lokomotywy ET22, zapewniając spełnienie wymagań bezpieczeństwa ruchu wg obowiązującego kryterium $\mathrm{Y} / \mathrm{Q} \leq 1,2$.

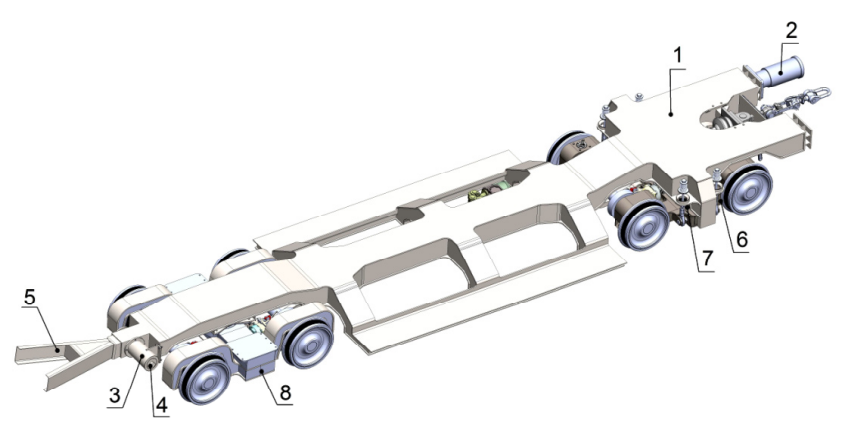

Rys. 2.24 - Model przestrzenny tylnego układu jezdnego z wózkiem środkowym przesuwnym

Przeanalizowano możliwość oparcia ramy nośnej 1 na wózku środkowym 8 na kulistym czopie skrętu przesuwnym poprzecznie $\pm 180 \mathrm{~mm}$ względem ramy wózka. Koncepcję takiego rozwiązania pokazano na rys. 2.24. Ramę nośną 1 wyposażoną $\mathrm{z}$ jednej strony $\mathrm{w}$ urządzenia pociagowo-zderzne 2 , a $\mathrm{z}$ drugiej $\mathrm{w}$ wspornik $3 \mathrm{z}$ mechanizmem 4 do połączenia przedniego układu jezdnego 5, oparto na wózku końcowym 6 za pośrednictwem podpór gumowych 7 adaptowanych z loko-motywy ET22, a drugi koniec ramy na przesuwnym poprzecznie wózku środkowym 8 .

Model wózka środkowego przedstawia rys. 2.25.

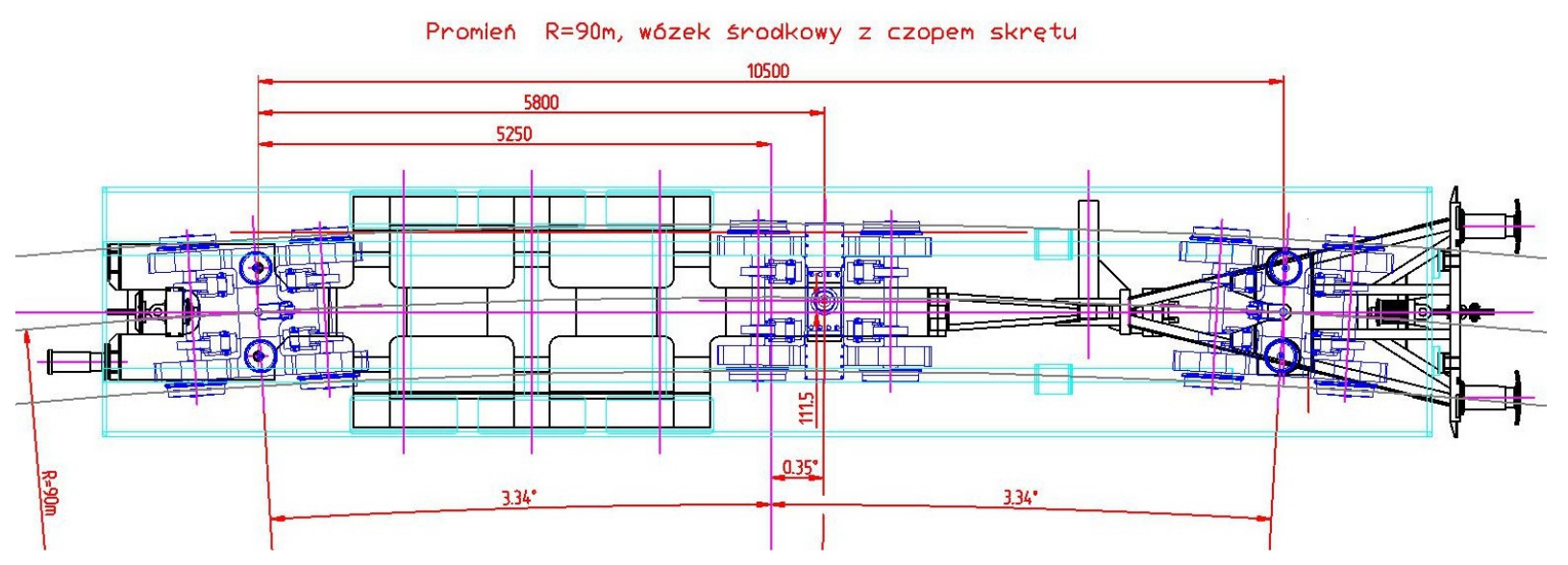

Rys. 2.23 - Pojazd w łuku toru o promieniu $90 \mathrm{~m} \mathrm{z}$ wózkiem środkowym na kulistym czopie skrętu przesuwnym poprzecznie 


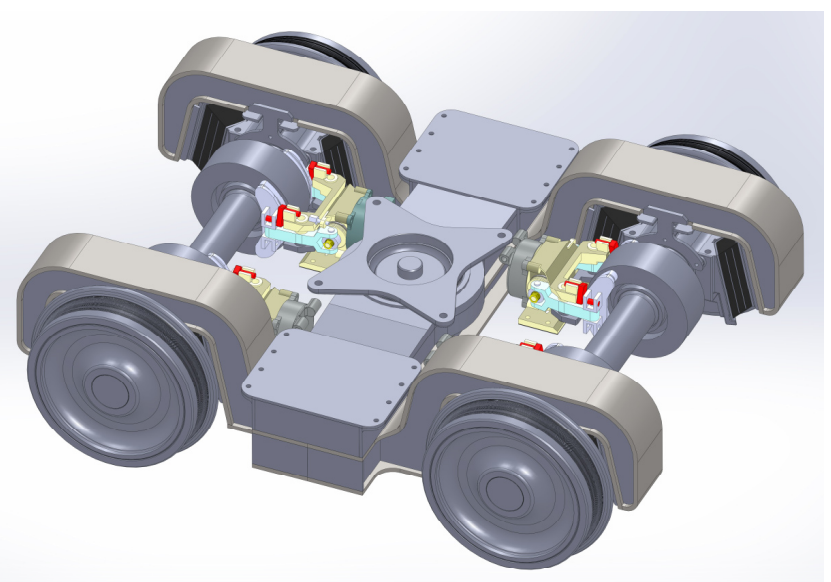

Rys. 2.25 - Model wózka środkowego z poprzecznie przesuwnym czopem skrętu

$\mathrm{Na}$ rys. 2.25 zilustrowano widok przekroju poprzecznego wózka środkowego gdzie na ramie wózka 1 zabudowano mechanizm przesuwu poprzecznego czopa skrętu 2. Przesuw poprzeczny czopa skrętu względem ramy wózka zrealizowano za pomocą rolek tocznych 3 na których oparto belkę $4 \mathrm{z}$ zabudowanym czopem skrętu 2. Końce belki 4 umieszczono na rolkach tocznych 3, które mogą przetaczać się po pochyłych podstawach 5 .

Dobierając odpowiednie pochylenie płaszczyzn podstawy, tak aby rolki toczne w stanie środkowym wózka były usytuowana w położeniu najniższym podczas przetaczania się rolek w obydwie strony wzdłuż osi poprzecznej wózka powstaje siła zwrotna, która po przemieszczeniu poprzecznym wózka względem czopa skrętu (rys. 2.26) powoduje powrót wózka do położenia środkowego. Natomiast obrót wózka względem osi pionowej jest realizowany na typowym (wagonowym) czopie skrętu .

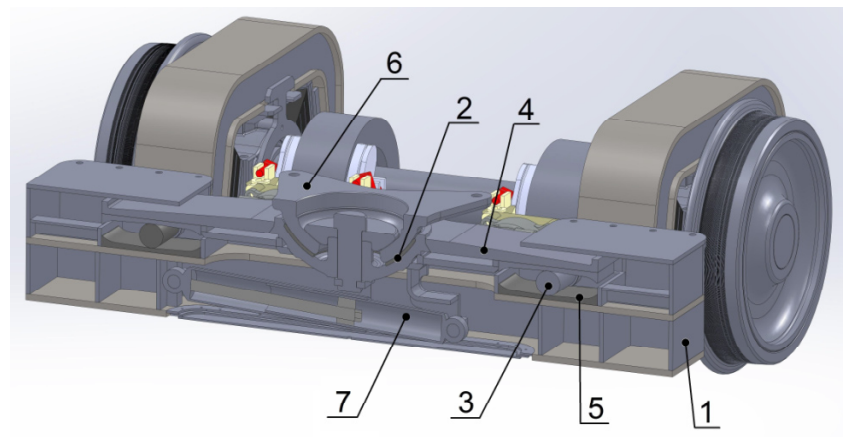

Rys. 2.26 - Widok przekroju przez czop skrętu oraz rolkowy mechanizm przesuwu poprzecznego

Do wytłumienia niekontrolowanych drgań poprzecznych wózka 8 (rys. 2.24) względem ramy nośnej 1 (rys. 2.26) pomiędzy belką przesuwną 4 a ramą wózka zabudowano thumik hydrauliczny 7 lub inny mechanizm thumiący o odpowiedniej charakterystyce tłumienia. Wadą tej konstrukcji jest odmienność konstrukcji wózka środkowego od wózków końcowych czyli brak unifikacji głównych zespołów układu biegowego.
Na rys. 2.27 pokazano usytuowanie czopa skrętu w skrajnym położeniu.

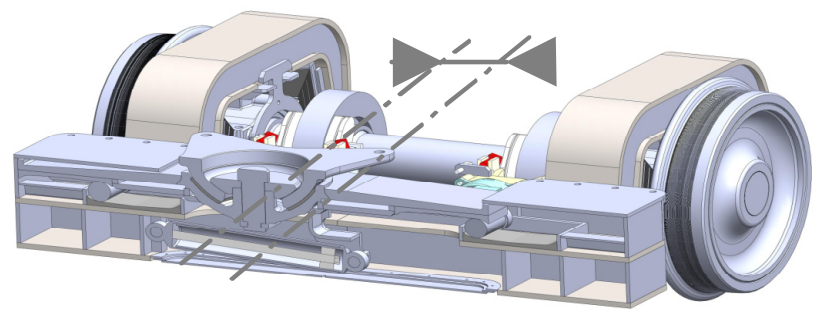

Rys. 2.27 - Przemieszczenie czopa skrętu w skrajne lewe położenie

Ostatecznie w dążeniu do unifikacji układów biegowych (wózków) podjęto decyzję zastosowania nowo zaprojektowanych podpór gumowych rys. $2.28 \mathrm{o}$ sztywności pionowej takiej jak w podporach lokomotyw ET22 lecz dużo mniejszej sztywności poprzecznej, które zabudowano na wózkach końcowych i wóz$\mathrm{ku}$ środkowym. Takie rozwiązanie usprężynowania drugiego stopnia umożliwiło zwiększenie poprzecznych przemieszczeń podpór na wózkach skrajnych i zmniejszenia ich na wózku środkowym do wartości pozwalającej na przejazd pojazdu przez łuki o małych promieniach toru przy poprzecznym oddziaływaniu na tor kół prowadzących zestawów kołowych spełniających warunki bezpieczeństwa $\mathrm{Y} / \mathrm{Q} \leq 1,2$.

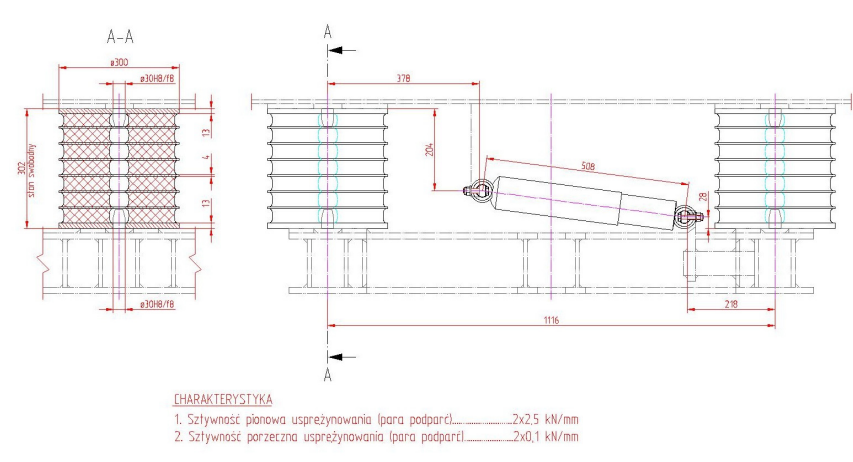

Rys. 2.28 - Zaprojektowane podpory gumowe

Wyniki analiz dawały podstawę do przyjęcia ostatecznej wersji rozwiązania konstrukcyjnego. Rozwiązanie to, przedstawione na rysunku 2.29 składa się z modułu dwóch naczep 1 posadowionych na wózkach połączonych ze soba. Układ jezdny przedni 2 wraz z adapterowym układem podparcia przodu naczepy wyposażony jest $\mathrm{w}$ urządzenia pociagowo zderzne. Układ jezdny tylny 3 składa się z dwóch wózków jezdnych połączonych pomiędzy sobą platformą załadowczą. Tylny i przedni są spięte między sobą układem rozłącznym. Sprzężenie pomiędzy układem jezdnym przednim i tylnym jest rozłączne aby umożliwić załadunek naczepy. Dwie naczepy stanowią moduł transportowy połączony pomiędzy sobą za pomocą sprzęgów. 


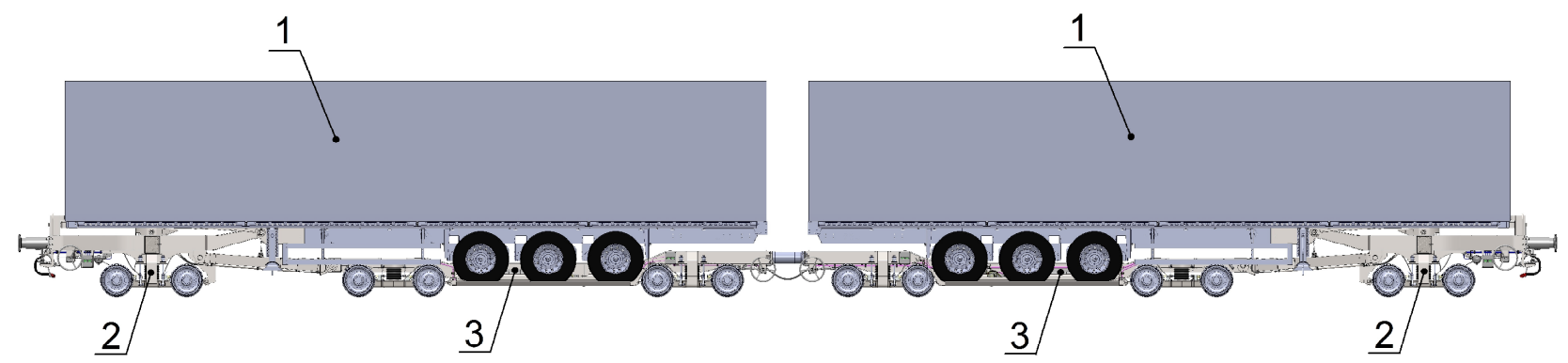

Rys. 2.29 - Rozwiązanie z połączeniem pomiędzy układem jezdnym przednim i tylnym

\section{Podsumowanie}

Prezentowane w artykule nowatorskie rozwiązanie jest kolejnym krokiem w rozwoju transportu intermodalnego. W porównaniu do poprzednich rozwiązań połączyło niektóre cechy konstrukcyjne stosowanych dotychczas wagonów platform i systemów bimodalnych eliminując znaczący przyrost masy naczepy bimodalnej przez zachowanie w tym samym miejscu punktów podparcia ramy naczepy w trakcji drogowej i kolejowej.

Autorzy artykułu zaprezentowali poszczególne etapy procesu projektowego. Wiele rozwiązań, nawet tych, które nie zostały zastosowane do ostatecznego rozwiązania, ma na celu pokazać $\mathrm{w}$ jaki sposób kształtuje się konstrukcja. Autorzy mają nadzieję, że zaprezentowany materiał będzie miał charakter edukacyjny, szczególnie dla konstruktorów, którzy dopiero rozpoczynają swoją przygodę z projektowaniem.

\section{Literatura:}

1. Medwid M.: Polski system transportu kolejowodrogowego (bimodalnego) typu TABOR. Instytut Pojazdów Szynowych „TABOR”. 2006.

2. Medwid M., Cichy R., Przepióra K.: Geometryczna analiza meganaczepy bimodalnej na wózkach bezadapterowych. XVII Konferencja Naukowa „Pojazdy Szynowe”. Kazimierz Dolny 2006.

3. Medwid M., Szerbart R.: Optymalizacja parametrów konstrukcyjnych zespołów pociagu bimodalnego typu TABOR. Pojazdy Szynowe nr 1, 2004.

4. Sprawozdanie merytoryczne z realizacji projektu rozwojowego $\mathrm{nr}$ 10-0065-10 pt.: "System transportu naczep drogowych na wózkach kolejowych w kombinowanym ruchu kolejowo - drogowym" - Archiwum IPS , TABOR” 